\title{
Asymmetrical Carbonyl Stretching Bands in the Infrared Spectra of Esters
}

\author{
HEIMO LAATO and REINO ISOTALO \\ Department of Chemistry, University of Turku, Turku 2, Finland
}

\begin{abstract}
The positions of the infrared carbonyl bands of 64 esters dissolved in hexane, acetonitrile and chloroform have been determined with an infrared grating spectrophotometer connected to a continuous balance potentiometer. Most of the studied esters whose acyl groups have one or two electronegative $\alpha$-substituents have a double carbonyl stretching band in the infrared region owing to their occurrence as mixtures of conformational isomers.
\end{abstract}

\begin{abstract}
It has been found that the infrared spectra of many esters of monochloro1 acetic and dichloroacetic acids contain a double carbonyl stretching band. ${ }^{1}$ The aim of the present study was to determine whether a double or multiple carbonyl band is characteristic of the spectra of esters with asymmetrically located substituents in their acyl groups.

A double carbonyl band has not been observed in Raman spectra of alkyl mono- and dihalogenoacetates ${ }^{2}$ and only infrared spectra of a few of these esters contain such a band. ${ }^{3}$ Evidently this has been due to the use of instruments of insufficient resolving power or to excessive intensity of the band which has precluded an examination of its fine structure. The form of the carbonyl band in an intense spectrum (cell thickness $0.1 \mathrm{~mm}$, for example) can, however, often be determined by studying the carbonyl stretching overtone band which lies in the $3650-3400 \mathrm{~cm}^{-1}$ region. ${ }^{1}$

When Josien and co-workers ${ }^{4,5}$ measured the spectra of dilute solutions of a number of alkyl mono- and dihalogenoacetates and allyl phenoxyacetate in carbon tetrachloride, a clear difference was noted between the branched carbonyl bands in these spectra and the simple carbonyl bands in the spectra of alkyl acetates and alkyl trichloroacetates measured for comparison. Bellamy and Williams ${ }^{6}$ showed that the high-frequency peak of the carbonyl band is due to the conformational isomer in which the halogen atom or atoms are close to the carbonyl group and the low-frequency peak to the conformational isomer in which the halogen atom or atoms are located farther from the carbonyl group. Brown ${ }^{7,8}$ and Neelakantan ${ }^{9}$ came to the same conclusion.
\end{abstract}


Table 1. Wave-numbers at which peaks of carbonyl bands occur in the infrared spectra of esters.

\begin{tabular}{|c|c|c|c|c|}
\hline No. & Ester & Hexane & $\begin{array}{c}\text { Solvent } \\
\text { Acetonitrile }\end{array}$ & Chloroform \\
\hline 1. & $\mathrm{CH}_{3} \mathrm{COOCH}_{3}$ & 1756.0 & 1742.6 & 1737.9 \\
\hline 2. & $\mathrm{CH}_{3} \mathrm{COOCH}_{2} \mathrm{OC}_{4} \mathrm{H}_{9}-\mathrm{n}$ & $\begin{array}{l}1764.7 \\
1754.8\end{array}$ & $\begin{array}{l}1747.5 \\
(1734)\end{array}$ & 1739.9 \\
\hline 3. & $\mathrm{CH}_{2} \mathrm{FCOOCH}_{3}$ & 1789.8 & 1770.0 & 1767.0 \\
\hline & & 1758.6 & 1750.3 & 1750.5 \\
\hline 4. & $\mathrm{CH}_{2} \mathrm{FCOOCH}_{2} \mathrm{Cl}$ & 1808.3 & 1794.2 & 1794.8 \\
\hline 5. & $\mathrm{CH}_{2} \mathrm{ClCOOCH}_{3}$ & $\begin{array}{l}1781.0 \\
1781.4^{a}\end{array}$ & $\begin{array}{l}1775.3 \\
1761.1^{b}\end{array}$ & $\begin{array}{l}1775.1 \\
1758.0\end{array}$ \\
\hline & & 1755.0 & $(1746)$ & $(1746)$ \\
\hline 6. & $\mathrm{CH}_{2} \mathrm{ClCOOCH}_{2} \mathrm{Br}$ & $\begin{array}{l}1798.9 \\
1773.9\end{array}$ & $\begin{array}{l}1786.5 \\
1765.3\end{array}$ & $\begin{array}{l}1785.7 \\
1767.0\end{array}$ \\
\hline & & $1737.9^{c}$ & $(1740)^{c}$ & $(1734)^{c}$ \\
\hline 7. & $\mathrm{CH}_{2} \mathrm{ClCOOCHCl}_{2}$ & $\begin{array}{l}1807.0 \\
1783.5\end{array}$ & $\begin{array}{l}1796.9^{d} \\
1781.6\end{array}$ & $\begin{array}{l}1796.7 \\
(1774)\end{array}$ \\
\hline & & $1737.9^{c}$ & $\operatorname{sh}^{c}$ & $\operatorname{sh}^{c}$ \\
\hline 8. & $\mathrm{CH}_{2} \mathrm{ClCOOCHClCH}_{2} \mathrm{Cl}$ & 1801.2 & 1789.6 & 1790.4 \\
\hline & & 1776.7 & 1770.6 & 1773.7 \\
\hline 9. & $\mathrm{CH}_{2} \mathrm{ClCOOCH}_{2} \mathrm{CH}=\mathrm{CH}_{2}$ & 1774.1 & 1759.4 & 1752.1 \\
\hline 10. & $\mathrm{CH}_{8} \mathrm{BrCOOCH}_{3}$ & $\begin{array}{l}1749.5 \\
(1774)\end{array}$ & $\begin{array}{l}(1745) \\
(1753)\end{array}$ & $(1741)$ \\
\hline 11. & $\mathrm{C}_{6} \mathrm{H}_{5} \mathrm{CH}_{2} \mathrm{COOCH}_{2} \mathrm{CH}_{2} \mathrm{CH}\left(\mathrm{CH}_{3}\right)_{2}$ & 1754.4 & $\begin{array}{l}1745.0 \\
(1736)\end{array}$ & 1741.8 \\
\hline & & 1746.2 & 1730.4 & 1728.9 \\
\hline 12. & $\mathrm{CHCl}_{2} \mathrm{COOCH}_{3}$ & $\begin{array}{l}1780.4^{e} \\
1759.9\end{array}$ & $\begin{array}{l}\text { 1768.0 } \\
1752.7\end{array}$ & $\begin{array}{l}1769.0 \\
1751.5\end{array}$ \\
\hline 13. & $\mathrm{CHCl}_{2} \mathrm{COOCHCl}_{2}$ & $\begin{array}{l}1805.2 \\
1783.2\end{array}$ & $\begin{array}{l}1798.19 \\
1784.1\end{array}$ & $\begin{array}{l}1796.5 \\
1780.0\end{array}$ \\
\hline $\begin{array}{l}14 . \\
15 . \\
16 .\end{array}$ & $\begin{array}{l}\mathrm{CClF}_{2} \mathrm{COOCH}_{3} \\
\mathrm{CF}_{3} \mathrm{COOCH}_{2} \mathrm{CH}_{3} \\
\mathrm{CH}_{3} \mathrm{CHClCOOCH}_{3}\end{array}$ & $\begin{array}{l}1791.2 \\
1792.0^{h} \\
(1775)\end{array}$ & $\begin{array}{l}1785.1 \\
1786.3^{i}\end{array}$ & $\begin{array}{l}1780.8 \\
1783.2^{j}\end{array}$ \\
\hline 17. & $\mathrm{CH}_{3} \mathrm{CHClCOOCH}_{2} \mathrm{Cl}$ & $\begin{array}{l}1757.4 \\
(1793)\end{array}$ & 1751.5 & 1747.0 \\
\hline 18. & $\mathrm{CH}_{3} \mathrm{CHClCOOCH}_{2} \mathrm{CH}_{3}$ & $\begin{array}{l}1775.7 \\
(1766)\end{array}$ & 1770.0 & 1769.6 \\
\hline 19. & $\mathrm{CH}_{2} \mathrm{ClCH}_{2} \mathrm{COOCH}_{3}$ & $\begin{array}{l}1753.1 \\
1756.8 \\
(1750)\end{array}$ & $\begin{array}{l}1746.6 \\
1741.8\end{array}$ & $\begin{array}{l}1742.0^{k} \\
1737.3\end{array}$ \\
\hline $\begin{array}{l}20 . \\
21 .\end{array}$ & $\begin{array}{l}\mathrm{CH}_{2} \mathrm{ClCH}_{2} \mathrm{COOCH}_{2} \mathrm{CH}_{3} \\
\mathrm{CH}_{2} \mathrm{ClCH}_{2} \mathrm{COOCH}\left(\mathrm{CH}_{3}\right)_{2}\end{array}$ & $\begin{array}{l}1748.1 \\
1747.2 \\
1738.5\end{array}$ & $\begin{array}{l}1735.9 \\
1733.4\end{array}$ & $\begin{array}{l}1733.6 \\
1726.5\end{array}$ \\
\hline $\begin{array}{l}22 . \\
23 . \\
24 .\end{array}$ & $\begin{array}{l}\mathrm{CH}_{3} \mathrm{CHBrCOOCH}_{3} \\
\mathrm{CH}_{3} \mathrm{CHBrCOOCH}_{2} \mathrm{CH}_{3} \\
\mathrm{CH}_{2} \mathrm{BrCH}_{2} \mathrm{COOCH}_{3}\end{array}$ & $\begin{array}{l}1754.4 \\
1748.5 \\
1755.8 \\
(1750)\end{array}$ & $\begin{array}{l}1742.0 \\
1737.7 \\
1739.9\end{array}$ & $\begin{array}{l}1741.8 \\
1734.0^{\ell} \\
1736.5\end{array}$ \\
\hline 25. & $\mathrm{CH}_{2} \mathrm{BrCH}_{2} \mathrm{COOCH}_{2} \mathrm{CH}_{3}$ & $\begin{array}{l}1751.3 \\
(1746)\end{array}$ & 1737.7 & 1732.2 \\
\hline 26. & $\mathrm{CH}_{3} \mathrm{CCl}_{2} \mathrm{COOCH}_{3}$ & 1775.1 & $\begin{array}{l}1759.7 \\
1752.1\end{array}$ & $\begin{array}{l}(1760) \\
1750.7\end{array}$ \\
\hline 27. & $\mathrm{CH}_{3} \mathrm{CCl}_{2} \mathrm{COOCH}_{2} \mathrm{CH}_{3}$ & 1768.6 & 1754.6 & $(1750)$ \\
\hline 28. & $\mathrm{CH}_{3} \mathrm{CCl}_{2} \mathrm{COOCH}_{2} \mathrm{CH}_{2} \mathrm{Cl}$ & $\begin{array}{l}1750.9 \\
1774.5\end{array}$ & $\begin{array}{l}1745.8 \\
1762.3\end{array}$ & 1744.2 \\
\hline & & 1757.6 & 1753.4 & 1755.2 \\
\hline
\end{tabular}




\begin{tabular}{|c|c|c|c|c|}
\hline No. & Ester & Hexane & $\begin{array}{c}\text { Solvent } \\
\text { Acetonitrile }\end{array}$ & Chloroform \\
\hline 29. & $\mathrm{CH}_{3} \mathrm{CCl}_{2} \mathrm{COOCCl}_{2} \mathrm{CH}_{3}$ & $\begin{array}{l}1809.9^{m} \\
1790.6 \\
1776.7\end{array}$ & $\begin{array}{l}1800.9^{n} \\
1784.5 \\
(1778)\end{array}$ & $\begin{array}{l}1804.6 \\
1783.9\end{array}$ \\
\hline 30. & $\mathrm{CH}_{3} \mathrm{CCl}_{2} \mathrm{COOC}_{3} \mathrm{H}_{7}-\mathrm{n}$ & $\begin{array}{l}1770.6 \\
1752.7\end{array}$ & $\begin{array}{l}1753.6 \\
1745.2\end{array}$ & $\begin{array}{l}(1754) \\
1743.4\end{array}$ \\
\hline 31. & $\mathrm{CH}_{3} \mathrm{CCl}_{2} \mathrm{COOC}_{4} \mathrm{H}_{9}-\mathrm{n}$ & $\begin{array}{l}1768.0 \\
1749.9\end{array}$ & $\begin{array}{l}1756.0 \\
1746.6\end{array}$ & $\begin{array}{c}\text { sh } \\
1741.3\end{array}$ \\
\hline 32. & $\mathrm{CH}_{3} \mathrm{CCl}_{2} \mathrm{COOC}_{5} \mathrm{H}_{11}-\mathrm{n}$ & $\begin{array}{l}1769.8 \\
1751.7\end{array}$ & $\begin{array}{l}1756.2 \\
1746.4\end{array}$ & $\begin{array}{c}\text { sh } \\
1743.6\end{array}$ \\
\hline 33. & $\begin{array}{l}\mathrm{CH}_{2} \mathrm{ClCHClCOOCH}_{3} \\
\mathrm{CH}_{2} \mathrm{ClCHClCOOCH}_{2} \mathrm{CH}_{3}\end{array}$ & $\begin{array}{l}1783.5 \\
1766.2 \\
(1776)\end{array}$ & $\begin{array}{l}(1767) \\
1752.7\end{array}$ & 1752.5 \\
\hline $\begin{array}{l}35 . \\
36 . \\
37 . \\
38 . \\
39 . \\
40 . \\
41 .\end{array}$ & $\begin{array}{l}\mathrm{CF}_{3} \mathrm{CF}_{2} \mathrm{COOCH}_{2} \mathrm{CH}_{3} \\
\mathrm{CCl}_{2}=\mathrm{CClCOOCH} \\
\mathrm{CH}_{3} \mathrm{CH}_{2} \mathrm{CH}\left(\mathrm{C}_{6} \mathrm{H}_{5}\right) \mathrm{COOCH}_{3} \\
\mathrm{CH}_{3} \mathrm{CH}_{2} \mathrm{CH}\left(\mathrm{CO}_{6} \mathrm{H}_{5}\right) \mathrm{COOCH}_{2} \mathrm{CH}_{3} \\
\left(\mathrm{CH}_{3}\right)_{2} \mathrm{CBrCOOCH}_{2} \mathrm{CH}_{3} \\
\mathrm{NCCOOCH}_{3} \\
\mathrm{NCCH}_{2} \mathrm{COOCH}_{2} \mathrm{CH}_{3}\end{array}$ & $\begin{array}{l}1759.4 \\
1787.9 \\
1744.2 \\
1745.6 \\
1739.9 \\
1742.8 \\
1762.9 \\
1761.3 \\
(1750)\end{array}$ & $\begin{array}{l}1746.4 \\
1781.2 \\
1737.1 \\
1733.8 \\
1728.9 \\
1733.8 \\
1759.2 \\
1751.3^{p}\end{array}$ & $\begin{array}{l}1747.9 \\
1779.4 \\
1734.8 \\
1731.0 \\
1727.7 \\
1730.2^{\circ} \\
1756.4 \\
1750.5\end{array}$ \\
\hline 42. & $\mathrm{HOCH}_{2} \mathrm{COOCH}_{3}$ & & 1754.0 & \\
\hline 43. & $\mathrm{CH}_{3} \mathrm{OCH}_{2} \mathrm{COOCH}_{3}$ & $\begin{array}{l}1774.5 \\
(1765)\end{array}$ & $\begin{array}{l}(1742) \\
(1775) \\
1755.0\end{array}$ & 1752.7 \\
\hline 44. & $\mathrm{CH}_{3} \mathrm{OCH}_{2} \mathrm{COOCH}_{2} \mathrm{CH}_{3}$ & 1750.3 & 1738.9 & $(1736)$ \\
\hline & & $\begin{array}{l}1764.1 \\
1744.0\end{array}$ & $\begin{array}{l}1754.0 \\
1734.0\end{array}$ & $\begin{array}{l}1749.9 \\
(1736)\end{array}$ \\
\hline $\begin{array}{l}45 . \\
46 .\end{array}$ & $\begin{array}{l}\mathrm{CH}_{3} \mathrm{OCH}_{2} \mathrm{COOCH}_{2} \mathrm{CH}_{2} \mathrm{Cl} \\
\mathrm{CH}_{3} \mathrm{OCH}_{2} \mathrm{COOC}_{3} \mathrm{H}_{7}-\mathrm{n}\end{array}$ & $\begin{array}{l}1770.8 \\
1750.3 \\
(1776)\end{array}$ & $\begin{array}{l}1759.7 \\
1740.3\end{array}$ & $\begin{array}{l}1759.5 \\
(1736)\end{array}$ \\
\hline & & $\begin{array}{l}1765.8 \\
1745.2\end{array}$ & $\begin{array}{l}1751.9 \\
1730.6\end{array}$ & $\begin{array}{l}1747.9 \\
\text { sh }\end{array}$ \\
\hline 47. & $\mathrm{CH}_{3} \mathrm{OCH}_{2} \mathrm{COOCH}\left(\mathrm{CH}_{3}\right)_{2}$ & sh & & \\
\hline 48. & $\mathrm{CH}_{3} \mathrm{OCH}_{2} \mathrm{COOC}_{4} \mathrm{H}_{9}-\mathrm{n}$ & $\begin{array}{l}1738.1 \\
(1775)\end{array}$ & 1729.6 & $\begin{array}{l}1740.8 \\
\text { sh }\end{array}$ \\
\hline 49. & $\mathrm{CH}_{3} \mathrm{OCH}_{2} \mathrm{COOC}\left(\mathrm{CH}_{3}\right)_{3}$ & $\begin{array}{l}1764.9 \\
1744.6 \\
(1767)\end{array}$ & $\begin{array}{l}1751.7 \\
1731.0\end{array}$ & $\begin{array}{l}1747.5 \\
\text { sh }\end{array}$ \\
\hline & & $\begin{array}{l}1756.6 \\
1736.7\end{array}$ & $\begin{array}{l}1747.7 \\
1728.3\end{array}$ & $\begin{array}{l}1745.2 \\
(1720)\end{array}$ \\
\hline 50. & $\mathrm{CH}_{3} \mathrm{OCH}_{2} \mathrm{COSCH}_{3}$ & $\begin{array}{l}1716.3 \\
(1703) \\
1697.0 \\
(1686)\end{array}$ & $\begin{array}{l}1702.5 \\
(1698) \\
1687.2 \\
(1677)\end{array}$ & $\begin{array}{l}(1701) \\
(1696) \\
1683.2 \\
(1673)\end{array}$ \\
\hline 51. & $\mathrm{CH}_{3} \mathrm{OCCl}_{2} \mathrm{COOCH}_{3}$ & $\begin{array}{l}1779.8 \\
(1768)\end{array}$ & 1768.6 & 1766.6 \\
\hline 52. & $\mathrm{CH}_{3} \mathrm{CH}_{2} \mathrm{OCH}_{2} \mathrm{COOCH}_{3}$ & $\begin{array}{l}1772.7 \\
1749.1\end{array}$ & $\begin{array}{l}1758.6 \\
1739.5\end{array}$ & $\begin{array}{c}1756.4 \\
\text { sh }\end{array}$ \\
\hline
\end{tabular}




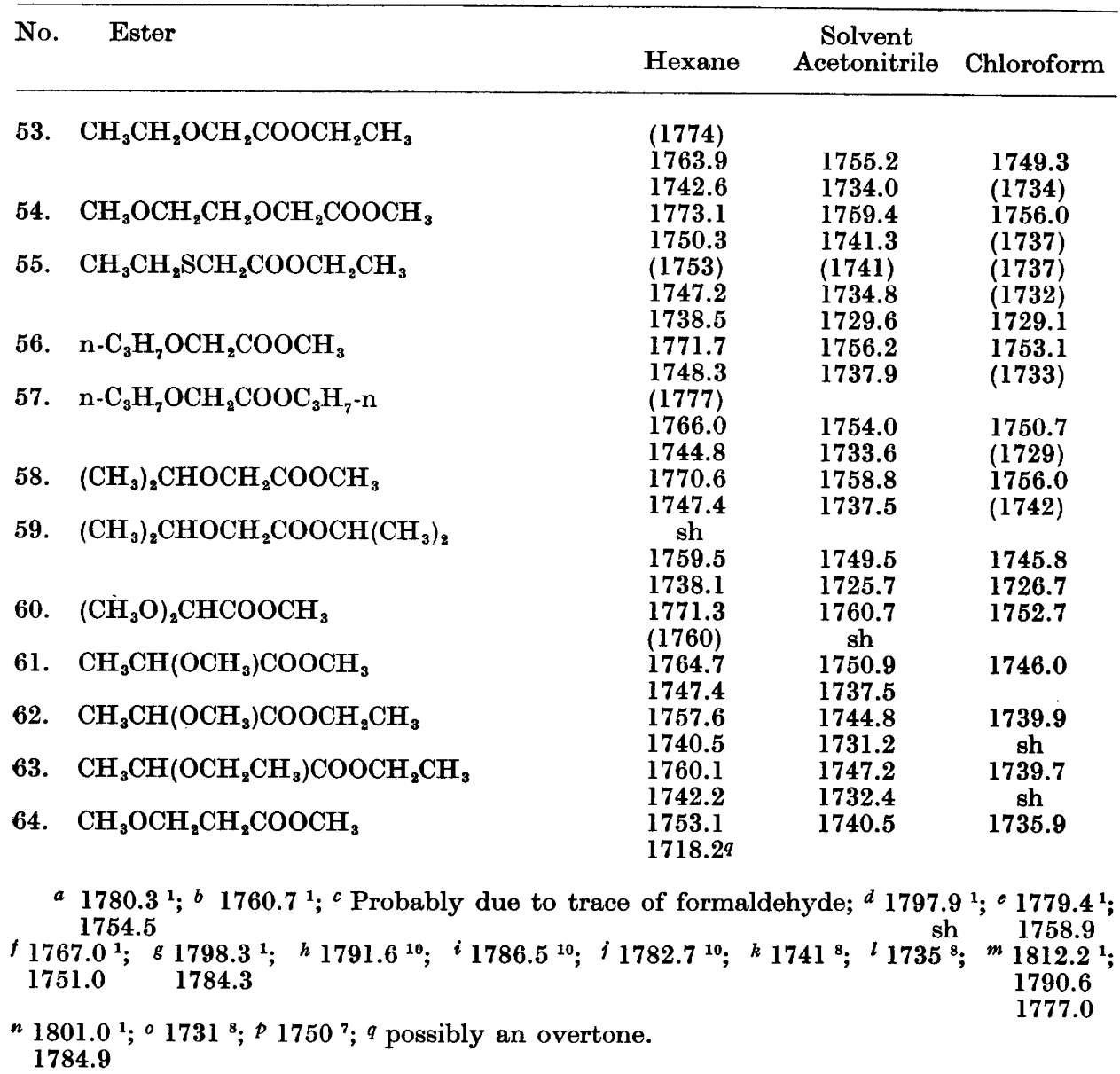

According to Brown, ${ }^{8}$ the conformational isomers of ethyl monohalogenoacetates have the co nformations I (cis) and II (gauche) and the conformational isomers of ethyl dihalogenoacetates the conformations III and IV.
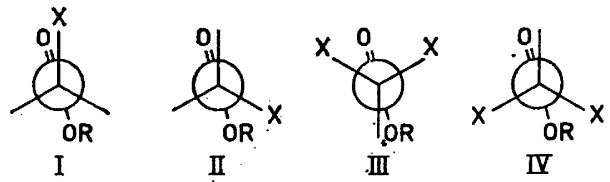

RESULTS AND DISCUSSION

The wave-numbers at which the peaks of the carbonyl bands were found in the spectra of the solutions of the studied esters in hexane, acetonitrile and chloroform are listed in Table 1. 
The shift of the carbonyl absorption peak resulting from a change from a solvent (hexane) of low polarity to one (acetonitrile) of high polarity varies greatly from ester to ester (Table 1). This shift to lower wave-numbers is greatest for unsubstituted esters (methyl acetate, No. 1 , shift $13 \mathrm{~cm}^{-1}$ ) and the high-frequency conformations (I) of methyl monohalogenoacetates (methyl monofluoroacetate, No. $3,20 \mathrm{~cm}^{-1}$ ) and smallest for esters of fully halogenated acids (methyl difluoromonochloroacetate, No. 14, $6 \mathrm{~cm}^{-1}$; ethyl trifluoroacetate, No. 15, $6 \mathrm{~cm}^{-1}$; ethyl pentafluoropropionate, No. $35,7 \mathrm{~cm}^{-1}$; methyl trichloroacrylate, No. $36,7 \mathrm{~cm}^{-1}$ ) and the low-frequency conformations (II) of esters of monohalogenoacetic acids (methyl monofluoroacetate, No. $3,8 \mathrm{~cm}^{-1}$ ). The peaks of the carbonyl bands of both conformations of esters of $\alpha$-alkoxysubstituted acids shift about $10 \mathrm{~cm}^{-1}$. The carbonyl bands are less resolved in the spectra of the esters in chloroform than in the spectra of the esters in acetonitrile; only in a few of the former spectra are the two peaks observed (Fig. 1 and Table 1). According to Kagarise and Whetsel, ${ }^{10}$ who recorded the spectra of ethyl acetate, ethyl trichloroacetate, and ethyl trifluoroacetate in hexane-chloroform mixtures, the hypsochromic shift is due to two factors: the solute-solvent complex absorbs at a lower wave-number when the solvent is chloroform, the shift depending on the structure of the ester, and the change in dielectric constant shifts the carbonyl band peak approximately the same number of wave-numbers (about $4 \mathrm{~cm}^{-1}$ ) with all esters.

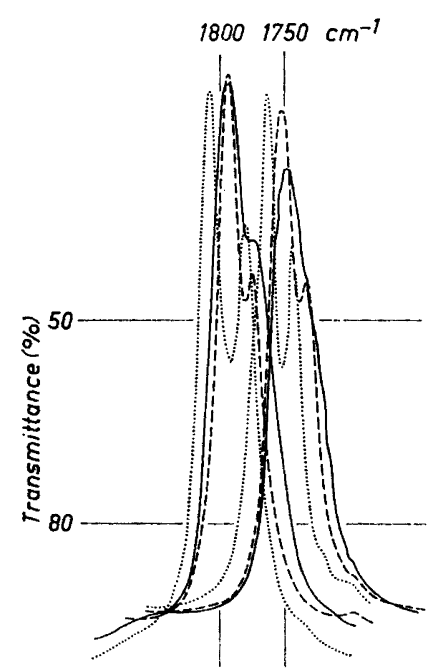

Fig. 1. Carbonyl bands of monochloromethyl monofluoroacetate (No. 4) and ethyl methoxyacetate (No. 44). Solvent: … hexane, - - chloroform.

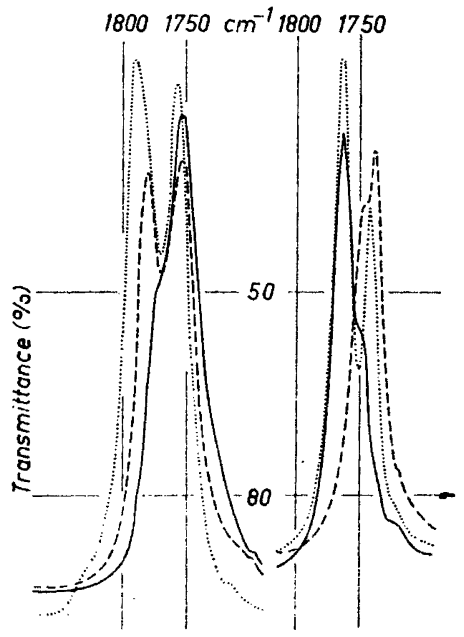

Fig. 2. Carbonyl bands in the infrared spectra of esters dissolved in hexane. Left: ... methyl monofluoroacetate (No. 3), - - methyl monochloroacetate (No. 5), methyl monobromoacetate (No. 10). Right: .... ethyl ethoxyacetate (No.53), - - ethyl ethylmercaptoacetate (No. 55), — ethyl cyanoacetate (No. 41).

Acta Chem. Scand. 21 (1967) No. 8 
In general, the carbonyl bands of different esters of the same acid are closely similar in form. Structural changes in the alkyl groups of the esters may lead to a change in the number and proportions of conformational isomers, which influence the form of the composite carbonyl band. This is shown by the double carbonyl band of butoxymethyl acetate (No. 2) and the simple carbonyl band of methyl acetate (No. 1), and the triple carbonyl band of $\alpha, \alpha$-dichloroethyl $\alpha, \alpha$-dichloropropionate (No. 29) and the double carbonyl bands of other esters of $\alpha, \alpha$-dichloropropionic acid (Nos. 26-28, 30-32).

An examination of the carbonyl bands of the $\alpha$-monosubstituted acetates (alkyl monofluoroacetates, Nos. 3 and 4; alkyl monochloroacetates, Nos. 5-9; methyl monobromoacetate, No. 10; isoamyl phenylacetate, No. 11; ethyl cyanoacetate, No. 41; alkyl monoalkoxyacetates, Nos. 43-49, 52-54, $56-59$; ethyl ethylmercaptoacetate, No. 55) reveals that the intensity of the high-frequency peak diminishes with decreasing electronegativity and/or the size of the substituent (Fig. 2). The carbonyl band of methyl glycolate (No. 42) seems to be symmetrical and is located at a low wave-number in the spectrum of the ester in hexane; an intramolecular hydrogen bond apparently stabilizes this ester. The carbonyl band of the ester in acetonitrile has a little shoulder on the low-frequency side, which may be a sign of a different conformation of the ester.

The slight asymmetry of the band peak in the spectra of alkyl propionates with an electronegative substituent on the $\beta$ carbon atom (alkyl $\beta$-chloropropionates, Nos. 19-21; alkyl $\beta$-bromopropionates, Nos. 24 and 25; methyl $\beta$-methoxypropionate, No. 64) may be due to the occurrence of these esters

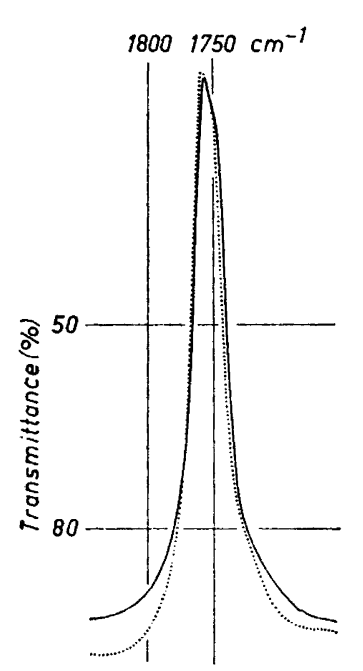

Fig. 3. Carbonyl bands in the infrared spectra of esters dissolved in hexane. .... Methyl $\beta$-chloropropionate (No. 19), - methyl $\beta$-bromopropionate (No. 24).

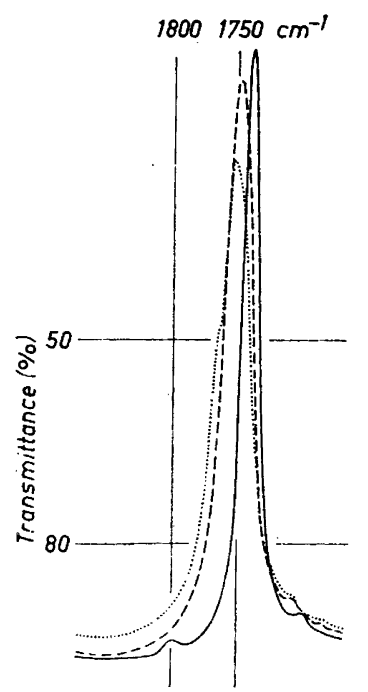

Fig. 4. Carbonyl bands in the infrared spectra of esters dissolved in hexane. .... Ethyl $\alpha$-chloropropionate (No. 18),

- - ethyl $\alpha$-bromopropionate (No. 23), ethyl $\alpha$-phenylbutyrate (No. 38).

Acta Chem. Scand. 21 (1967) No. 8 
as conformations in which the distance between the $\beta$ substituent and the carbonyl oxygen differs considerably (Fig. 3).

Of the $\alpha, \alpha$-disubstituted acetate esters (alkyl dichloroacetates, Nos. 12 and 13; alkyl $\alpha$-chloropropionates, Nos. 16-18; alkyl $\alpha$-bromopropionates, Nos. 22 and 23; alkyl $\alpha, \beta$-dichloropropionates, Nos. 33 and 34; alkyl $\alpha$-phenylbutyrates, Nos. 37 and 38; methyl dimethoxyacetate, No. 60; alkyl $\alpha$-alkoxypropionates, Nos. $61-63$ ), the $\alpha$-bromopropionate and $\alpha$-phenylbutyrate esters do not seem to occur in the conformation with the electronegative substituent near the carbonyl oxygen because their carbonyl bands are narrow and are located at relatively low wave-numbers (Fig. 4). $\alpha$-Chloropropionates in hexane give rise to a carbonyl band with a shoulder on the high-frequency side (Fig. 4); the shoulder is evidently due to a conformation with the chlorine atom near the carbonyl oxygen. The branches of the carbonyl bands of the conformational isomers are clearly separated and approximately equal in intensity in the spectra of the dichloroacetates and $\alpha$-alkoxypropionates, whereas methyl dimethoxyacetate occurs mainly in the conformation (evidently conformation III) whose carbonyl group absorbs at the higher wavenumber (Fig. 5). When the positions and shapes of the carbonyl bands of $\alpha, \beta$-dichloropropionates are compared with those of the carbonyl bands of the $\alpha$-monochlorinated acetates and propionates, it is seen that the predominating conformational isomers of the $\alpha, \beta$-dichloropropionates absorb at frequencies between the frequencies of the carbonyl band peaks of the conformational isomers of the $\alpha$-monosubstituted esters (Fig. 6).

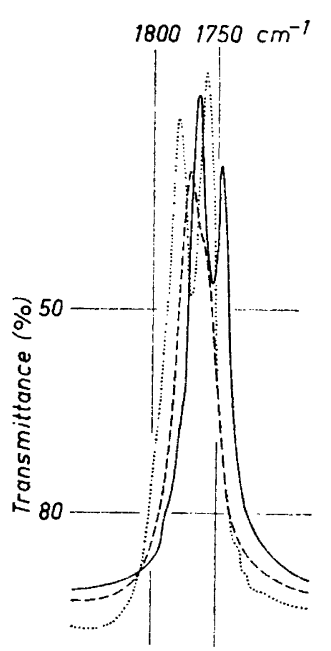

Fig. 5. Carbonyl bands in the infrared spectra of esters dissolved in hexane. .... Methyl dichloroacetate (No. 12),

- - methyl dimethoxyacetate (No. 60), - methyl $\alpha$-methoxypropionate (No. 61).

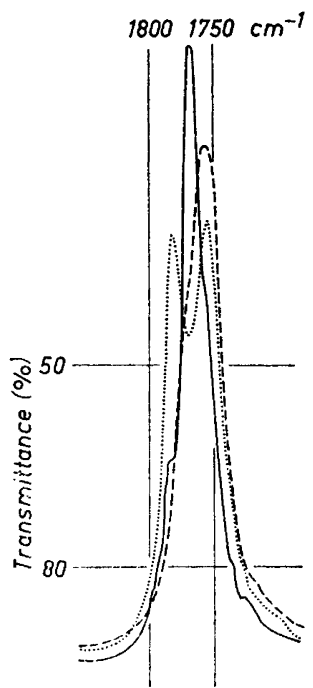

Fig. 6. Carbonyl bands in the infrared spectra of esters dissolved in hexane. .... Methyl monochloroacetate (No. 5),

- - methyl $\alpha$-chloropropionate (No. 16), methyl $\alpha, \beta$-dichloropropionate (No. 33).

Acta Chem. Scand. 21 (1967) No. 8 


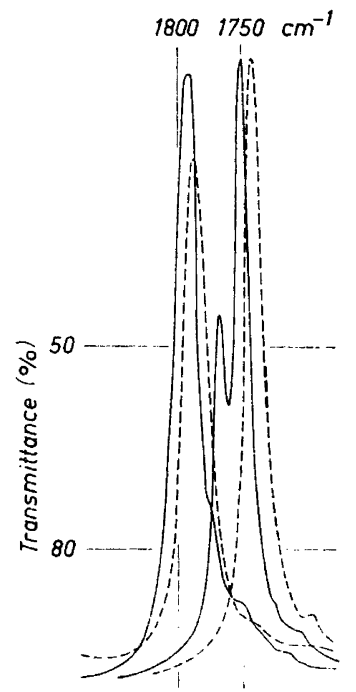

\begin{abstract}
Fig. $\%$. Carbonyl bands in the infrared spectra of esters dissolved in hexane. The bands from left to right: ethyl trifluoroacetate (No. 15), ethyl pentafluoropropionate (No. 35), ethyl $\alpha, \alpha$-dichloropropionate (No. 27), ethyl $\alpha$-bromoisobutyrate (No. 39).
\end{abstract}

Splitting of the carbonyl band does not occur when all three $\alpha$ substituents on the acyl side of the ester are identical (ethyl trifluoroacetate, No. 15) and only rarely when these substituents differ and there is no $\alpha$ hydrogen atom (methyl difluoromonochloroacetate, No. 14; ethyl pentafluoropropionate, No. 35; methyl trichloroacrylate, No. 36; ethyl $\alpha$-bromo-isobutyrate, No. 39; methyl methoxydichloroacetate, No. 51) (Fig. 7). The carbonyl bands of the alkyl $\alpha, \alpha$-dichloropropionates (Nos. 26-32) are branched (Fig. 7), indicating the presence of a low proportion of the conformational isomer (III) with chlorine atoms close to the carbonyl oxygen.

Changes in the alkyl groups of the esters influence mainly the location of the carbonyl bands. The peaks of the ethyl esters are located at wavenumbers $7 \mathrm{~cm}^{-1}$ lower than the peaks of the methyl esters when the solvent

Table 2. Shifts of carbonyl band peaks of esters caused by additional substituents in the alkyl groups of esters. Hexane solution.

\begin{tabular}{llrrrr}
\hline No. & Ester & & \multicolumn{2}{c}{$\begin{array}{c}\text { Wave-numbers } \\
\text { of peaks }\end{array}$} & $\begin{array}{c}\text { Band peak } \\
\text { shifts }\end{array}$ \\
\hline & & & & & \\
26 & $\mathrm{CH}_{3} \mathrm{CCl}_{2} \mathrm{COOCH}_{3}$ & 1775.1 & 1758.0 & & \\
27 & $\mathrm{CH}_{2} \mathrm{CH}_{3}$ & 1768.6 & 1750.9 & -6.5 & -7.1 \\
30 & $\mathrm{C}_{3} \mathrm{H}_{7}-\mathrm{n}$ & 1770.6 & 1752.7 & 2.0 & 1.8 \\
31 & $\mathrm{C}_{4} \mathrm{H}_{9}-\mathrm{n}$ & 1768.0 & 1749.9 & -1.4 & -2.8 \\
32 & $\mathrm{C}_{5} \mathrm{H}_{11}-\mathrm{n}$ & 1769.8 & 1751.7 & 1.8 & 1.8 \\
43 & $\mathrm{CH}_{3} \mathrm{OCH}_{2} \mathrm{COOCH}_{3}$ & 1774.5 & 1750.3 & & \\
44 & $\mathrm{CH}_{2} \mathrm{CH}_{3}$ & 1764.5 & 1744.0 & -10.2 & -6.3 \\
46 & $\mathrm{C}_{3} \mathrm{H}_{7}-\mathrm{n}$ & 1765.8 & 1745.2 & 1.7 & 1.2 \\
48 & $\mathrm{C}_{4} \mathrm{H}_{9}-\mathrm{n}$ & 1764.9 & 1744.6 & -0.9 & -0.6
\end{tabular}


is hexane and at wave-numbers $6 \mathrm{~cm}^{-1}$ lower when the solvent is chloroform. This is in accordance with previously recorded spectra of alkyl acetates $\left(8 \mathrm{~cm}^{-1}\right)$ and propionates $\left(5 \mathrm{~cm}^{-1}\right)$ in chloroform. ${ }^{11}$ Additional methyl groups at position $\alpha$ shift the carbonyl peak to lower wave-numbers, although less than the first methyl group (sec-propyl esters, Nos. 21 and 47; tert-butyl ester, No. 49). However, the carbonyl bands of the propyl esters seem to lie at slightly higher wave-numbers than those of the ethyl esters (Table 2). Possibly the orientation of the terminal methyl group may have some influence on the location of the carbonyl bands of the lower members of homologous esters. The main reason for the lower frequencies of the carbonyl bands of the ethyl esters compared with those of the methyl esters is the greater contributions of the mesomeric structures VI and VII to the resonance hybrid forms of the former esters. Similarly, halogen substituents on the alkyl groups increase,<smiles>[Y]OC(C)=O</smiles><smiles>[R1]OC(C)([O])OC</smiles><smiles>CC(=O)C(C)=O</smiles>

as stated previously, ${ }^{1}$ the proportion of structure $\mathrm{V}$ contributing to a resonance hybrid of the $\alpha$-chloroesters, which results in a marked bathochromic shift (monochloromethyl esters, Nos. 4 and 17, shifts $18-22 \mathrm{~cm}^{-1}$; monobromomethyl monochloroacetate, No. 6, shift $18-19 \mathrm{~cm}^{-1}$; dichloromethyl esters, Nos. 7 and 13, shifts $23-29 \mathrm{~cm}^{-1} ; \beta$-monochloroethyl esters, Nos. 28 and 45 , shifts 6-7 $\mathrm{cm}^{-1} ; \alpha, \beta$-dichloroethyl monochloroacetate, No. 8, shift 27-29 $\mathrm{cm}^{-1} ; \alpha, \alpha$-dichloroethyl $\alpha, \alpha$-dichloropropionate, No. 29 , shifts $40-41$ and $26 \mathrm{~cm}^{-1}$; all shifts in hexane). The triple carbonyl band of $\alpha, \alpha$-dichloroethyl $\alpha, \alpha$-dichloropropionate is in our opinion due to the following conformational isomers: the peak at the highest frequency to the conformation in which the four chlorine atoms are all close to the carbonyl oxygen, the middle peak to the conformations in which two chlorine atoms are near the carbonyl oxygen and two farther away, and the lowest frequency peak to the conformation in which all the chlorine atoms are far from the carbonyl oxygen.

\section{EXPERIMENTAL}

Chemicals. The studied esters are listed together with their physical constants in Table 3. The esters synthesized for this study are Nos. 14, 16, 19, 20, 22, 23, 26-28, $30-32,34-38,44,46-48,51,52,54,56,58,59$, and 62 . These esters, except methyl methoxydichloroacetate (No. 51), were prepared from the acids and the alcohols in the presence of $\boldsymbol{p}$-toluenesulphonic acid in a water entrainment unit that has been described earlier. ${ }^{10,20}$ The entrainer was methylene dichloride. Methyl methoxydichloroacetate (No. 51) was prepared by the method described by Scholl and Egerer.21 The esters Nos. $1,3,5,12,18,24,25$, and 60 and most of the acids and alcohols used in the syntheses were commercial chemicals from Fluka AG, isoamyl phenylacetate and $\alpha$-phenylbutyric acid from Dr. Theodor Schuchardt \& Co. GmbH, methyl monobromoacetate from The British Drug Houses Ltd., ethyl trifluoroacetate from L. Light \& Co. Ltd. The other esters, trichloroacrylic acid, and the alkoxy acids had been synthesized in the laboratory of the Department of Chemistry of the University of Turku. The esters were purified by

Acta Chem. Scand. 21 (1967) No. 8 


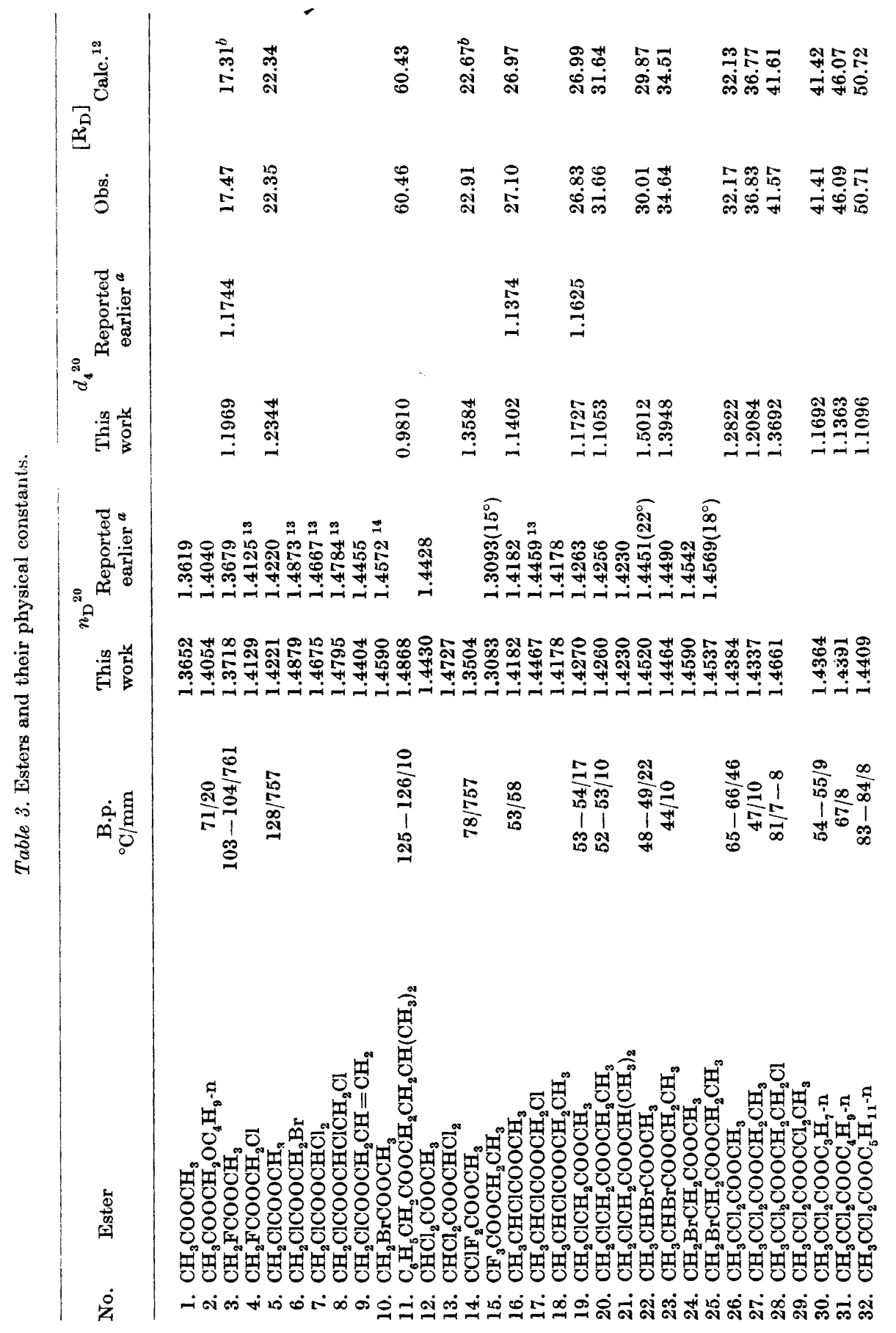

Acta Chem. Scand. 21 (1967) No. 8 


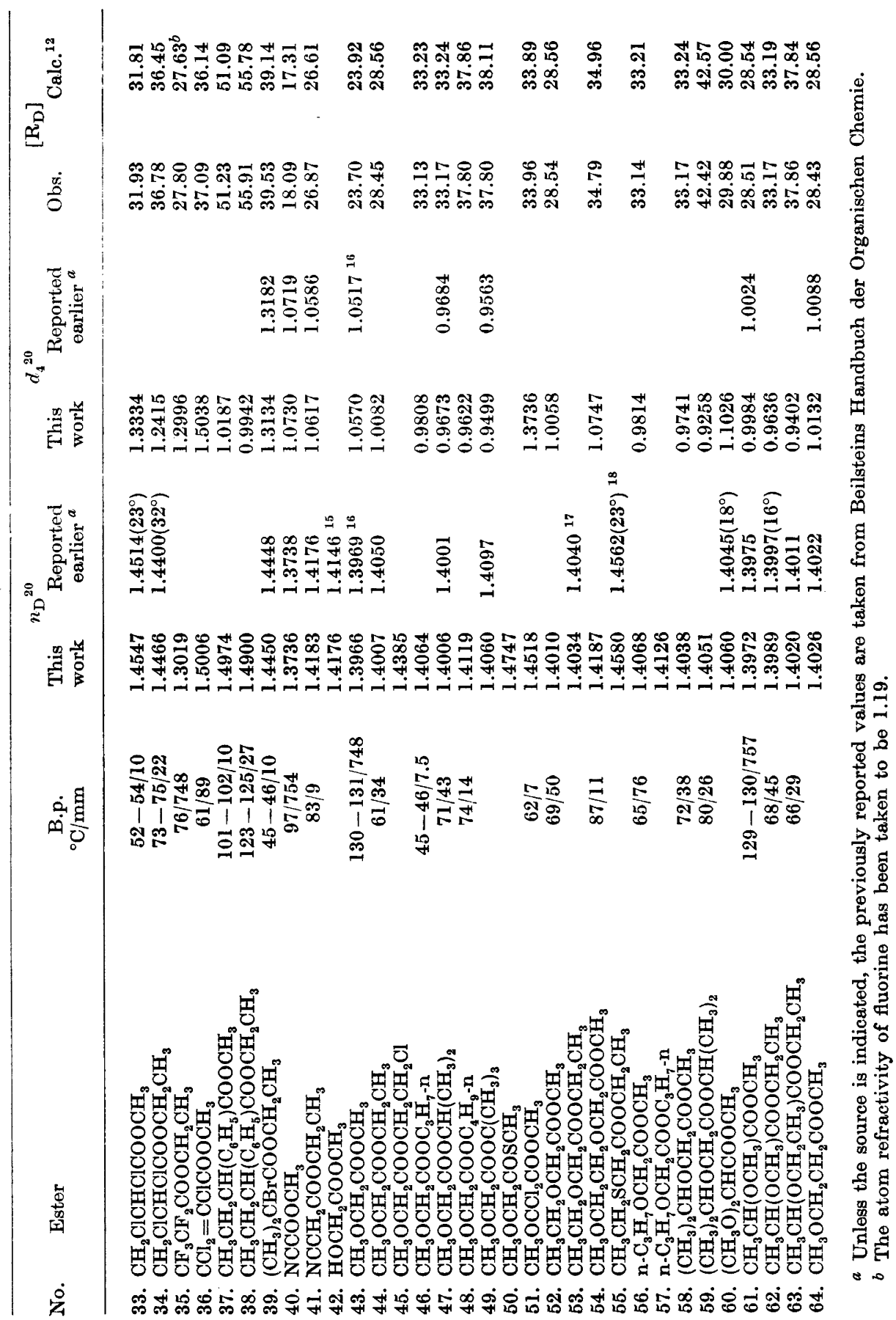

Acta Chem. Scand. 21 (1967) No. 8 
distillation if they were found by gas chromatography to contain more than $2 \%$ impurities. The solvents were from E. Merck AG.

Recording of infrared spectra. The infrared spectra were recorded with a PerkinElmer Model 337 Grating Infrared Spectrophotometer connected to a Honeywell Continuous Balance Potentiometer as described previously. ${ }^{1}$

The ester concentrations were $0.05 \mathrm{ml}$ in $5.0 \mathrm{ml}$ of solvent. Variable thickness liquid absorption cells with potassium bromide windows were employed in the recordings; the optical paths were about $0.1 \mathrm{~mm}$ in the measurements.

Acknowledgements. The authors are deeply indebted to Professor Reino Leimu, Ph. D. and Prof. Erkki Euranto, Ph. D., for samples of chemicals. Financial support received from the State Commission for Natural Sciences is gratefully acknowledged.

\section{REFERENCES}

1. Laato, H. Ann. Univ. Turkuensis, Ser. A I (1965) No. 86.

2. Cheng, H. Z. physik. Chem. B 24 (1934) 293.

3. McBee, E. T. and Christman, D. L. J. Am. Chem. Soc. 77 (1955) 755.

4. Josien, M.-L. and Calas, R. Compt. Rend. 240 (1955) 1641.

5. Josien, M.-L. and Castinel, C. Bull. Soc. Chim. France 1958801.

6. Bellamy, L. J. and Williams, R. L. J. Chem. Soc. 19574294.

7. Brown, T. L. J. Am. Chem. Soc. 80 (1958) 3513.

8. Brown, T. L. Spectrochim. Acta 18 (1962) 1615.

9. Neelakantan, P. Proc. Indian Acad. Sci. Sect. A 59 (1964) 385.

10. Kagarise, R. E. and Whetsel, K. B. Spectrochim. Acta 18 (1962) 341.

11. Katritzky, A. R., Lagowski, J. M. and Beard, J. A. T. Spectrochim. Acta 16 (1960) 964.

12. Vogel, A. I. J. Chem. Soc. 19481833.

13. Euranto, E. K., Noponen, A. and Kujanpää, T. Acta Chem. Scand. 20 (1966) 1273.

14. Euranto, E. K. and Moisio, A.-L. Suomen Kemistilehti B 37 (1964) 92.

15. Andreas, F. and Sowada, R. J. prakt. Chem. 13 (1961) 95.

16. Yrjänä, T. Ann. Univ. Turkuensis, Ser. A I (1962) No. 54.

17. Baganz, H. and Pflug, J. Chem. Ber. 90 (1957) 386.

18. Yale, H. L., Pribyl, E. J., Braker, W., Bernstein, J. and Lott, W. A. J. Am. Chem. Soc. 72 (1950) 3716.

19. Salmi, E. J. Ber. 71 (1938) 1803.

20. Laato, H. Suomen Kemistilehti B 38 (1965) 188.

21. Scholl, R. and Egerer, W. Ann. 397 (1913) 301.

Received April 27, 1967. 